Bulgarian Academy of Sciences. Space Research and Technology Institute.

Aerospace Research in Bulgaria. 30, 2018, Sofia

DOI: https://doi.org/10.3897/arb.v30.e13

\title{
MODELING OF THE CATASTROFIC VERSION OF A TRANSPORT AIRPLANE
}

\author{
Petar Getsov ${ }^{1,2}$, Dimitar Jordanov ${ }^{2}$, Wang Bo ${ }^{1}$ \\ ${ }^{1}$ Ningbo University of Technology - China \\ e-mail:bo305@hotmail.com \\ ${ }^{2}$ Space Research and Technology Institute -BAS, Bulgaria \\ e-mail:director@space.bas.bg
}

\begin{abstract}
Under the description of the crash is modeled the main crash-version. On the basis of a model of the "pilot-control system-airplane" system, the pilot actions in case offailure of the damping machine from the directional steering control system are analyzed.
\end{abstract}

\section{Problem under investigation}

The specific problem that is explored in the development is related to the following questions:

- Can a damping automat (DA) failure in the transport plane management system cause destructive overloads for the structure?

- What should be the pilot's actions in the developing emergency situation to prevent the crash?

\section{Introduction}

The flight safety theory has the task of responding to important operational issues of aircraft operation. Airborne disasters usually lack many of the facts that have to confirm or reject work versions in the investigation process. In such conditions, flight modeling and crew work in the process of developing the situation can give very important details to clarify the real causes of catastrophes. To illustrate this, modeling has attempted to analyze a Tu-134 plane crash in the 1970s over the territory of Croatia. The circumstances of this mysterious catastrophe are described by one of the leading investigators - Leonid Seliakov, chief designer at Tupolev's desk and author of the book "Man, Environment, Machine". The airplane has left parts of the airborne version, but the real reason is revealed years later when was found installation mistake on another plane: in one of the channels for the angular rate of risk (the reserve channel), the electrical signal goes to the reverse polarity 
DA. This means that if, at any given moment, the backup channel starts operating after the main one is canceled (to increase the reliability this channel is reserved), the DA will command a rudder to reverse the demand for normal operation. A largescale check is being carried out and such an error is detected on several other planes. Then, the most likely cause of the crash was the incorrect operation of DA due to an installation error.

The load and operation of the vertical stabilizer construction is limited to transport planes to breakdown overloads of $3.5 \ldots 4$. If, for any reason, this overload is reached during the operation, airborne damage occurs in the air starting from the vertical stabilizer. For the Tu-134, with a T-shaped taillight, breaking the vertical stabilizer means total loss not only of lateral stability and manageability but also of longitudinal. The emergency situation is short $(10 \ldots 15 \mathrm{~s})$, but with the horizontal stabilizer on the body, the pilot can prevent the whole plane from being destroyed. Such a favorable outcome of the situation was registered in 1964, a B-52 aircraft of the US Air Force. The plane continues flying for another 6 hours with a destroyed vertical stabilizer and landing successfully. Fig. 1 shows a photo (from the Internet) of this unique aviation case.

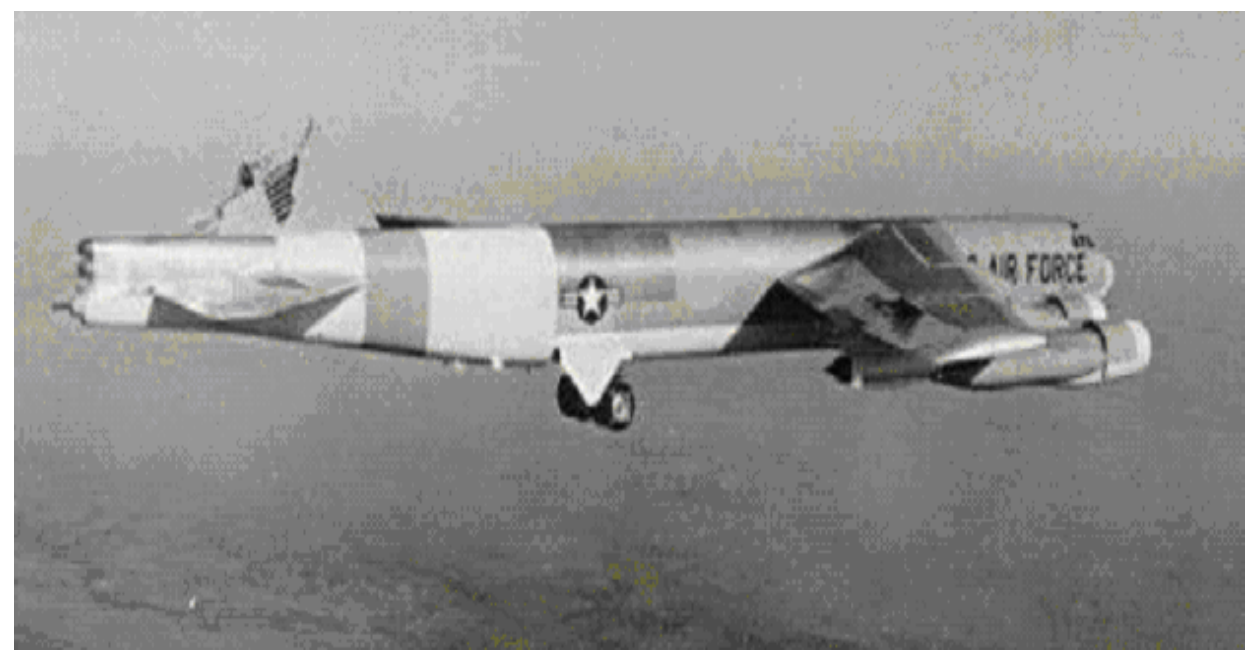

Fig. 1. During a test flight, the vertical stabilizer of the B-52H, flying at a height of about 5000 feet above New Mexico, is cut off in the event of large overloads. Six hours later, the crew managed to make the first and only B-52 landing without a vertical stabilizer [6].

\section{Solution of research problem}

A model in standard GOST 20058-80 of the "Matlab-Simulink" emergency situation based on the "pilot-control-airplane" contour was developed [1,5]. Different consequences of failures in the damping machine (DM) from the rudder of 
control system and the action of a pilot model for pedal operation and the control lever in the lateral movement of the aircraft are analyzed.

The most important actions in creating a flight model are to select the means to fully reflect the peculiarities of the particular situation. In this case, the modeling is limited to Simulink's contours for coordinated controls with the ailerons and the rudder of the pilot models on these channels. The sideways airplane model is developed in the GOST 20058-80 standard on lateral motion equations known from flight dynamics $[2,4]$ with the coordinate system and designations specific to that standard.

$$
\begin{aligned}
& m V\left(\frac{d \beta}{d t}-\omega_{x} \alpha-\omega_{y}\right)=Z+G \cos \vartheta \sin \gamma \\
& I_{x} \frac{d}{d t} \omega_{x}=M_{x} \\
& I_{y} \frac{d}{d t} \omega_{y}=M_{y}
\end{aligned}
$$

where: $Z=Z^{\beta} \beta+Z^{\delta n} \delta_{n} ; \delta_{n}=\delta_{n \text { pilot }}+\delta_{n \text { damper }}$;

$$
\begin{aligned}
& M_{x}=M_{x}^{\beta} \beta+M_{x}{ }^{\omega x} \omega_{x}+M_{x}{ }^{\omega y} \omega_{y}+M_{x}{ }^{\delta e} \delta_{e}+M_{x}{ }^{\delta n} \delta_{n} ; \\
& M_{y}=M_{y}{ }^{\beta} \beta+M_{y}{ }^{\omega x} \omega_{x}+M_{y}{ }^{\omega y} \omega_{y}+M_{y}{ }^{\delta n} \delta_{n} .
\end{aligned}
$$

The behavior of a hypothetical transport airplane, close to its size, aerodynamics and a Tu-134 control system is modeled. For simplicity in modeling, the control wheel grip has been replaced with a central lever, with the stiffness of the aileron pointing to the handle. The main work channel is the pedaling control of the "yaw-motion" movement. This movement is leading in the interdependent fluctuations of the glide and slope angles of the Dutch-roll. The rudder steering system sums up the pilot and the damping machine.

The emergency situation begins after a model wind laterally disturbance at a speed of $30 \mathrm{~m} / \mathrm{s}$ at a height of $5000 \mathrm{~m}$ and a flight velocity of $860 \mathrm{~km} / \mathrm{h}$, failure of the main channel to form a signal proportional to the angular rate of risk and automatic switching of the reserve channel "mounting error" (supplying to the DM signal with reverse polarity).

The general appearance of the model for coordinated control of the airplane after failure of the DM is shown in Fig. 2. 


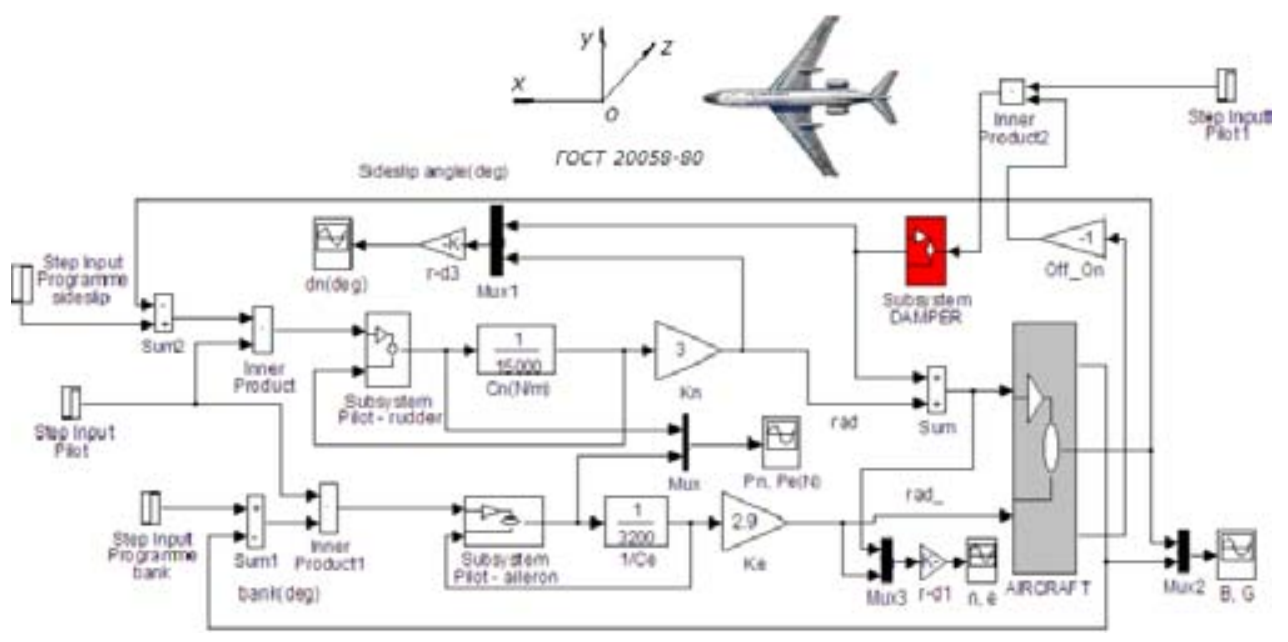

Fig. 2. Outriggers: Subsystem: DAMPER - model of the damping machine (Yaw damper); Pilot-rudder-pilot model Subsystem for steering with directional steering; Pilot-ailerons Subsystem - Pilot model for ailerons operation.

The figure shows the two contours for coordinated lateral movement control with ailerons and rudder. The prototype aircraft and model are equipped with a damping machine. The DA works with the rudder for a hydraulic actuator. In the case of an inoperative damping machine, the pilot should strive to maintain, above all, a steady control loop. The pilot's task is to recognize the refusal and to balance the airplane with zero roll and slip angles in the conditions of disruption and failure. Two modes of operation are tested in modeling: first - attempting to balance with a faulty DA and second - excluding a DA and then balancing the airplane.

On Fig. 3 is shown the pilot models and pilot co-pilot damping (DA). Under normal operation of the DA, the commands from it are opposed to the pilot's commands. Upon receiving a reverse polarity angular velocity, the pilot commands and the DA are unidirectional.

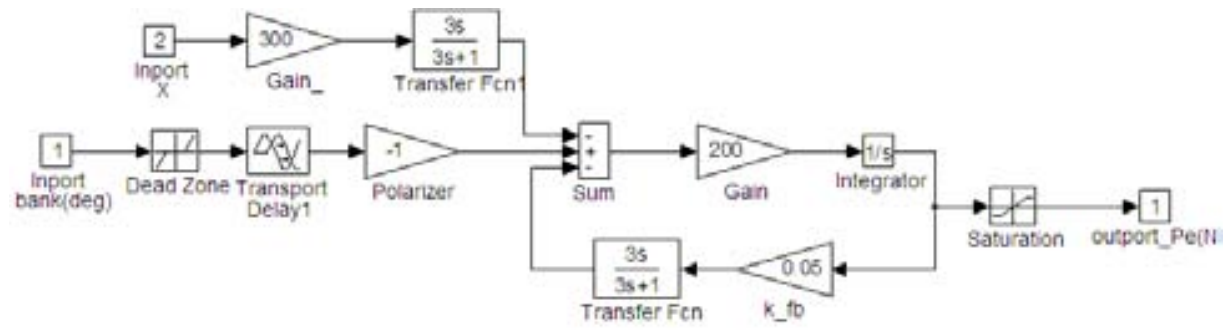

a) An aesthetic pilot model in the ailerons control channel 


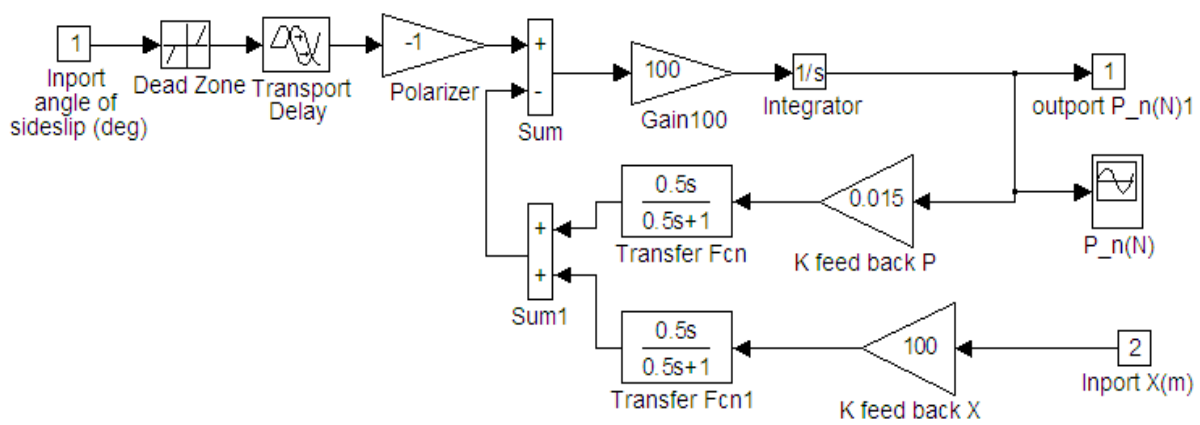

b) Aesthetic (with flexible feedback) pilot model for pedaling

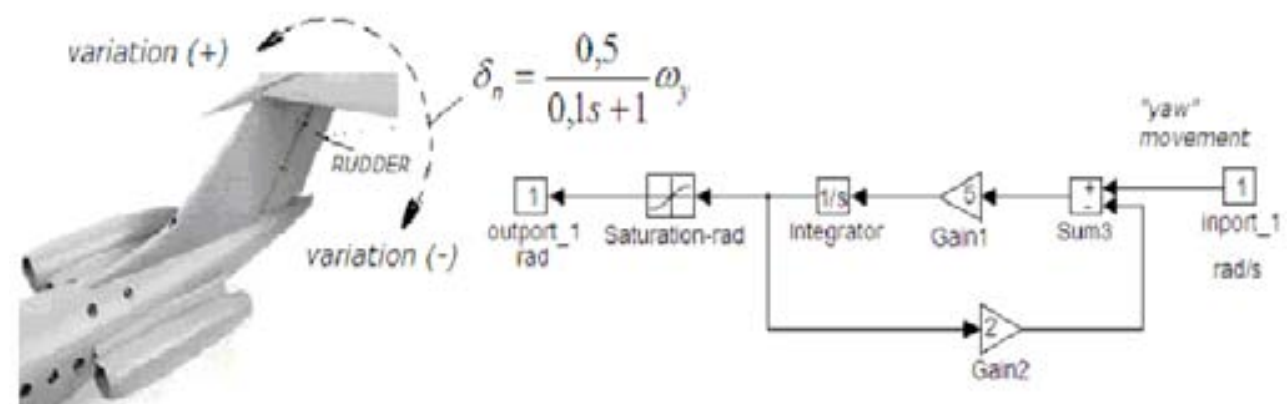

c) Model of the Yaw damper: The rudder deflection signal in DA operation is determined by the angular rate of risk at GOST 20058-80.

Fig. 3. Pilot and Damping Models in the channel to command the ailerons end rudder

\section{Results}

In Fig. 4 and Fig. 5 are represented the results of the variation of the basic parameters after failure of the main channel for forming an electrical signal to the executive of the DA and automatic switching of the reserved channel with an installation mistake leading to return of a revers polarity signal. This situation, as well as switching on and off, is achieved by adjusting the Off-On amplifier of the model in Fig. 1. For reverse polarity, this amplifier is set to "-1", for normal operation of "+1", and for OFF when "0" is set. 

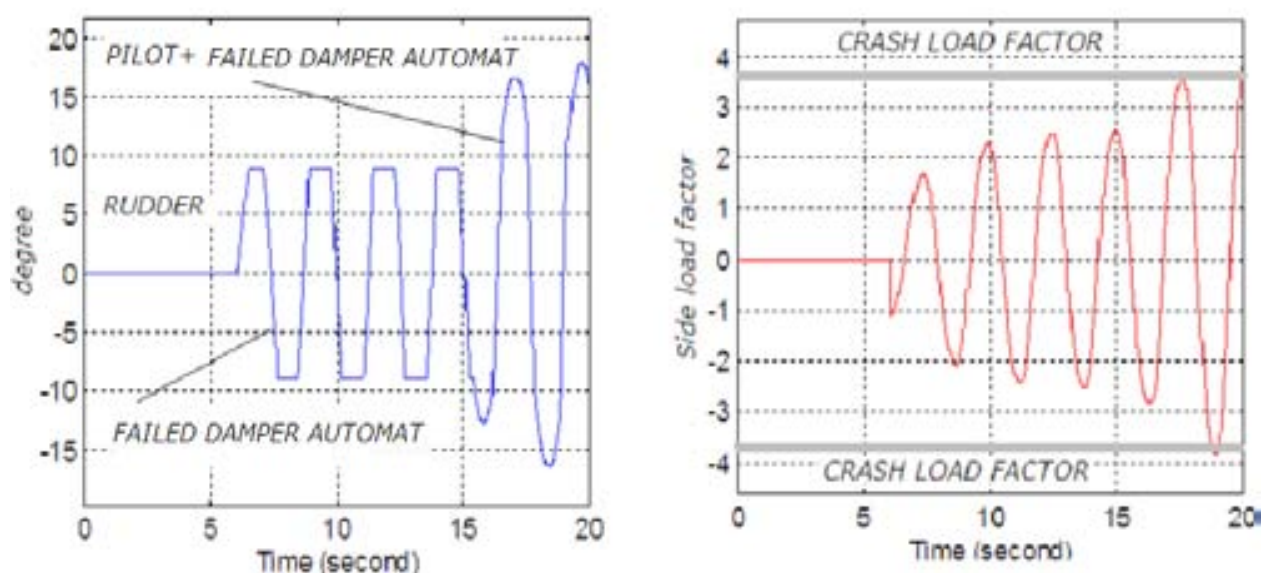

a) Deviation of the rudder and lateral overload in the event of incorrect pilot actions Faults the interference without excluding the failure DA
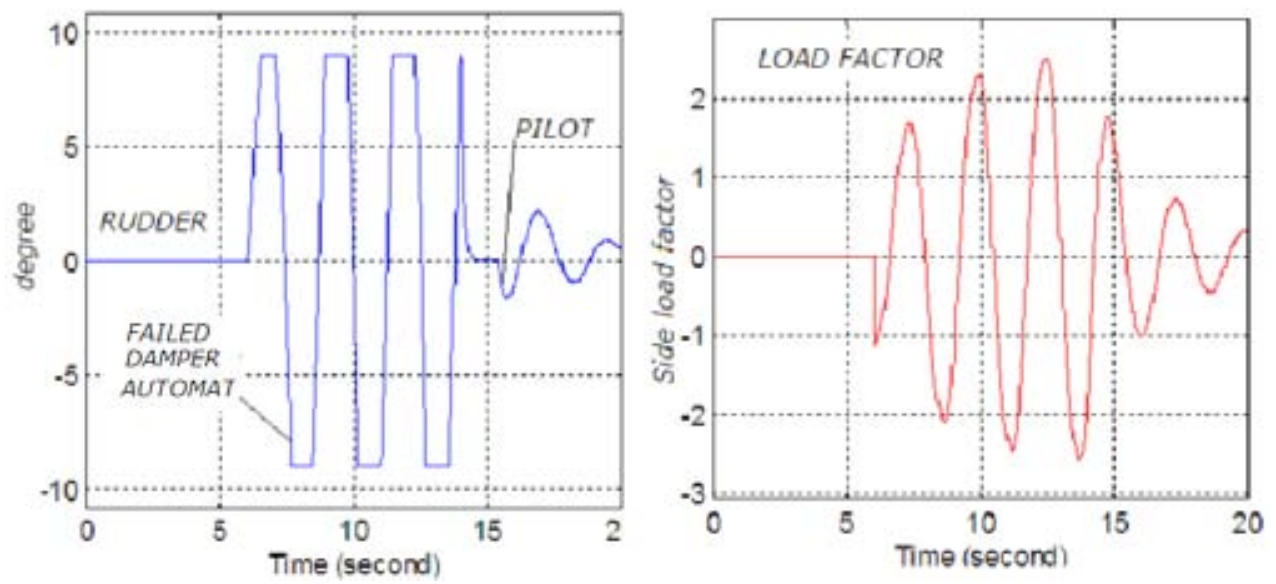

b) Deviation of rudder and lateral overload with correct pilot actions Fails the interference after shutting down the failure DA

Fig. 4. Deviation of rudder and lateral overload after failure (Reverse Polarity Type) of the DA for correct and incorrect operation of the pilot 

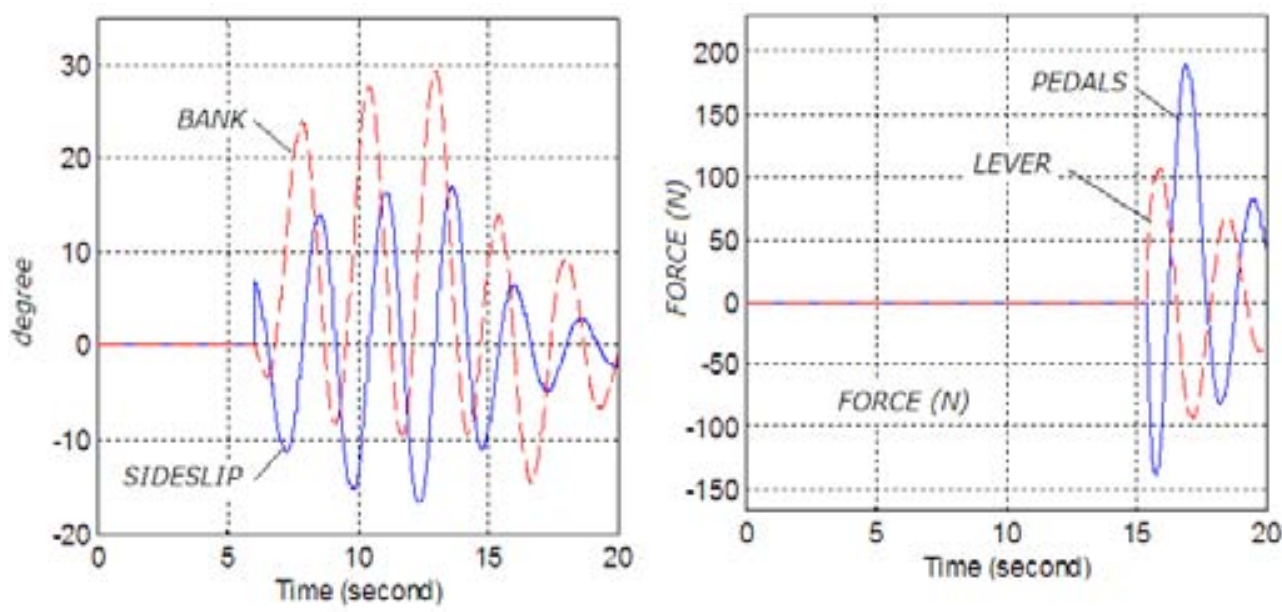

Fig. 5. Basic flight parameters (roll and slip angles) and pedal effort and the lever control for correct actions in the reverse polarity emergency situation of the DA; the pilot model starts working in $t_{\text {pilot }}=15 \mathrm{~s}$ after a turbulent

from strong lateral wind modeled in the seventh second $\left(t_{\text {disturbans }}=7 \mathrm{~s}\right)$.

\section{Conclusion}

- The modeling shows that pilots intervention (switch on DA) if the polarity of damping automat is incorrectly connected, the lateral overload may exceed the breakdown. It is result from the oscillating instability of the control loop (over control).

- In the case of correct pilot actions (switch off DA immediately), even in the case of an 8-second delay, no catastrophic situation occurs.

- In the event of a failure of feedback on the rudder machine (RM), the constructive limitations of the RM operation prevent the vertical stabilizer and the airplane from degrading overloads.

- It is most appropriate for the pilot to fix the controls around the neutral position until the fault is detected and to turn off the DA. The aircraft itself stops the fluctuations.

\section{Acknowledgements}

I. The study was performed with the use of the base:

1. Set up under the project BG161PO003-1.2.04-0053 "Information complex for aerospace environmental monitoring" (IKAMOS), financed by the operational program "Development of the competitiveness of the Bulgarian economy" 2007-2013, co-financed by the European regional development fund (ERDF) and from the national budget of the Republic of Bulgaria. 
2. Project "Strengthening and Expansion of the Aerospace Technology Transfer Office in the Field of Protection of Citizens' Health in Disasters" BG161PO0031.2.02 under the Operational Program "Development of the Competitiveness of the Bulgarian Economy" 2007-2013.

Foundation.

II. The authors gratefully acknowledge the support of K. C. Wong Education

\title{
References
}

1. Jordanov, D., P. Gecov. Unmanned aircraft - modeling and control. Third Scientific Conference with International Participaton "Space, Ecology, Nanotechnology, Safety", 27-29 June 2007, Varna, Bulgaria, http://www.space.bas.bg

2. Бороденко, В.А. и др. Самолет Ту 134, Транспорт, Москва, 1972.

3. Бадягин, А.А., С.М. Егер, В.Ф. Мишин, Ф.И. Склянский, Н.А. Фомин Проектирование самолетов, изд. "Машиностроение”, Москва, 1972.

4. Галашев, Е.С., Н.М. Лысенко и др. Аэродинамика и динамика полета маневренных самолетов, ВИ, Москва, 1984.

5. Гультяев, A.К. MATLAB 5.2 - Имитационного моделирования в среде Windows практическое пособие, Санкт Петербург, изд. “Корона принт”, 1999.

6. Димов, Н., Поразен от мълния бомбардировач В-52 каца успешно в базата си. сп. "Клуб КРИЛЕ". http://www.pan.bg/view_article-1-418653-porazen-ot-mylniyabombardirovach-B-52-kaca-uspeshno-v-bazata-si.html

\section{МОДЕЛИРАНЕ НА ВЕРСИЯ ЗА КАТАСТРОФА НА ТРАНСПОРТЕН САМОЛЕТ}

\author{
П. Гецов, Д. Йорданов, В. Бо
}

\section{Резюме}

В работата е моделирана основната версия за катастрофата на транспортен самолет по нейното описание от експертите. На базата на модел на системата "пилот-управление-самолет" се анализират действията на пилотите при аварийна ситуация в резултат на повреда на автомата за демпфериране от системата за управление. 